\title{
ANALISIS PENURUNAN MUKA TANAH DI KABUPATEN GRESIK TAHUN 2015 HINGGA 2017 DENGAN METODE PS-INSAR
}

\author{
Muhammad Taufik ${ }^{1}$, Ira Mutiara Anjasmara ${ }^{2}$, Rizki Fahrudin Ulin ${ }^{3}$ \\ 1,2,3 Departemen Teknik Geomatika FTSLK-ITS, Kampus ITS Sukolilo, Surabaya, 60111 \\ e-mail : ${ }^{1}$ taufik_m@geodesy.its.ac.id, ${ }^{2}$ ira@geodesy.its.ac.id, ${ }^{3}$ rizki.f.ulin@gmail.com
}

\begin{abstract}
Abstrak
Pergerakan penurunan muka tanah sering terjadi di berbagai wilayah di seluruh dunia khususnya kota-kota besar dan daerah pesisir. Dampak negatif dari penurunan muka tanah dapat berupa kerusakan sarana prasarana suatu wilayah. Penurunan muka tanah diduga disebabkan karena pengambilan air yang berlebihan untuk keperluan industri serta struktur pembentuk tanah yang ada pada wilayah tersebut. Untuk itu diperlukan adanya suatu kajian dengan tujuan untuk mitigasi bencana. Dampak dari bencana alam dapat diidentifikasi secara cepat dan akurat seiring dengan perkembangan teknologi menggunakan metode penginderaan jauh yang memiliki kemampuan mencakup area yang luas dan dalam waktu yang singkat. Pemilihan metode PS-InSAR berbasis Radar menjadi solusi tepat karena memiliki akurasi yang baik dan meminimalkan efek dekorelasi. Berdasarkan hasil pengolahan periode Mei 2015 hingga Januari 2016 dengan menggunakan metode PS-InSAR dalam analisis penurunan muka tanah pada Kabupaten Gresik, dihasilkan variasi nilai penurunan muka tanah antara $-49,35 \mathrm{~mm} /$ tahun hingga $54,95 \mathrm{~mm} /$ tahun dengan nilai rata-rata kecepatan penurunan muka tanah tertinggi pada Kecamatan Bungah. Metode ini terbukti sebagai salah satu metode penginderaan jauh yang baik untuk meneliti pergerakan penurunan muka tanah.
\end{abstract}

Kata Kunci : Penurunan muka tanah, PS-InSAR, Penginderaan Jauh, Radar

\begin{abstract}
Movement of land subsidence is common in many regions around the world, especially large cities and coastal areas. The negative impact of the land subsidence may be the destruction of a region's infrastructure. The land subsidence is thought to be caused by excessive water taking for industrial use and existing soil forming structures in the area. Therefore, a study with the objective of disaster mitigation is required. The impact of natural disasters can be identified quickly and accurately in line with technological developments using remote sensing methods that have the capability of covering large areas and in a short time. Selection of PS-InSAR based on Radar method to be the right solution because it has good accuracy and minimize the effect of decorelation. Based on the results of the processing period from May 2015 to January 2016 using PS-InSAR method in the analysis of land subsidence in Gresik Regency, the variation in the value of land subsidence decreased between $-49.35 \mathrm{~mm} /$ year to $54.95 \mathrm{~mm}$ / year with average value the highest rate of land subsidence at Bungah Sub-district. This method proved to be one of the best remote sensing methods to examine the movement of ground subsidence.
\end{abstract}

Keywords : Land Subsidence, PS-InSAR, Remote Sensing, Radar 


\section{PENDAHULUAN}

Proses penurunan muka tanah yang terjadi pada beberapa kota besar di Indonesia terutama di wilayah pesisir. Kondisi pada daerah pesisir sangat rentan karena struktur pembentuk batuan yang sangat riskan baik yang berasal dari daratan dan lautan. Selain faktor alamiah, faktor non-alamiah juga turut andi dalam proses penurunan muka tanah.

Kota Gresik termasuk kota Industri dan padat permukiman memiliki karakteristik struktur pembentuk batuan yang identik dengan wilayah Semarang dan Surabaya. Wilayah kecamatan Bungah dan Manyar memiliki struktur pembentuk batuan yang identik dengan Kota Surabaya bagian Utara. Posisi geografis yang terletak dekat dengan pesisir pantai serta sebagai daerah CBD (Centre Bussiness District) menjadikan perkembangan dan pertumbuhan menjadi sangat pesat. Hal ini dapat diketahui dengan meningkatnya pembangunan dan kegiatan industri dengan skala besar seperti Pabrik Semen Gresik, Perumahan Gresik Kota Baru, dan Rusunawa di daerah Prambangan. Hal tersebut secara langsung dan tidak langsung memberikan dampak buruk terhadap lingkungan sekitar.

Analisis besaran laju penurunan tanah dapat ditentukan berdasarkan hasil hitungan yang memiliki nilai yang signifikan. Ditinjau dari sudut pandang keilmuan geodesi dan geomatika, turunnya permukaan tanah dapat diketahui melalui titik referensi terhadap perubahan posisi vertikal. Oleh karena itu, diperlukan suatu kajian untuk menganalisa nilai perubahan secara kontinyu dan mencakup area yang luas serta waktu yang cepat dan efisien.

Penerapan Metode PS-InSAR yang termasuk dalam MTI (Multi Temporal InSAR) merupakan suatu langkah yang tepat untuk mengkaji suatu daerah yang mengalami penurunan muka tanah. Prinsip utama dari teknik PS-InSAR adalah memanfaatkan data pengamatan citra SAR multitemporal dalam rentang waktu panjang untuk mendeteksi titik-titik potensial koherensi.

Mayoritas negara yang sudah maju sudah menggunakan teknologi sensor SAR ini sebagai sensor pencitraan. Indonesia secara perlahan mulai memulai untuk mengembangkan sensor SAR. Meskipun pennggunaan dan pengembangan sistem ini belum sepenuhnya sempurna dibandingkan negara lain yang sudah memiliki riset beberapa tahun lalu, namun langkah ini sebagai awal yang baik untuk penggunaan untuk inovasi dan investasi jangka panjang.

Pada penelitian ini digunakan metode PSInSAR dengan wilayah penelitian yang berlokasi di Kabupaten Gresik. Pengolahan yang digunakan dalam penelitian ini adalah penerapan Teknik PSInSAR untuk mengetahui sebaran titik titik PS (Permanent Scatterer). Dari hasil pengolahan tersebut akan menghasilkan daerah potensi penurunan muka tanah wilayah Kabupaten Gresik sehingga mendapatkan analisis mengenai daerah yang mengalami penurunan muka tanah tertinggi dan terendah.

\section{METODOLOGI PENELITIAN}

\section{Lokasi Penelitian}

Lokasi penelitian ini mengambil studi kasus di wilayah Kabupaten Gresik, berlokasi di $112^{\circ} 21^{\prime} 57.4^{\prime \prime}-112^{\circ} 40^{\prime} 38.8^{\prime \prime}$ Bujur Timur dan $6^{\circ} 50^{\prime} 29.2^{\prime \prime}-7^{\circ} 24^{\prime} 30.2^{\prime \prime}$ Lintang Selatan.

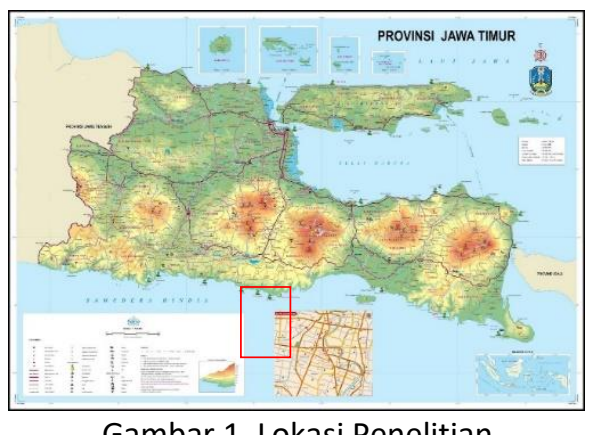

Gambar 1. Lokasi Penelitian

\section{Data dan Peralatan}

- Data

Data yang digunakan dalam penelitian ini adalah Citra Sentinel 1-A SLC dan Peta Geologi Skala 1: 100.000.

- Peralatan

Peralatan yang digunakan dalam penelitian ini adalah software Pengolahan Data SAR (SNAP).

\section{Pengolahan Data}

1. Tahap Persiapan

- Identifikasi Masalah

Identifikasi masalah memiliki tujuan untuk mengetahui teknik StaMPS pada metode PS-InSAR. Teknik ini digunakan untuk menganalisis permukaan tanah kota gresik pada tahun 2015 hingga tahun 2017 menggunakan data citra satelit Sentinel-1A multi temporal. Pemilihan daerah 
penelitian dimana pasangan citra radar SLC (Single Look Complex) yang memenuhi syarat koherensi digunakan. Dalam PSInSAR, kebutuhan data yang digunakan baik penggunaan citra radar yang rapat secara temporal dan tidak melebihi 7 tahun dari akuisisi data awalnya.

- Studi Literatur

Studi Literatur dilakukan untuk mempelajari dan mengumpulkan bukubuku referensi dan hasil penelitian sejenis sebelumnya yang pernah dilakukan oleh orang lain yang berkaitan sebagai landasan teori mengenai masalah yang akan diteliti pada tahap pengolahan dari referensi lain yang mendukung baik dari buku, jurnal, majalah, internet dan lain sebagainya.

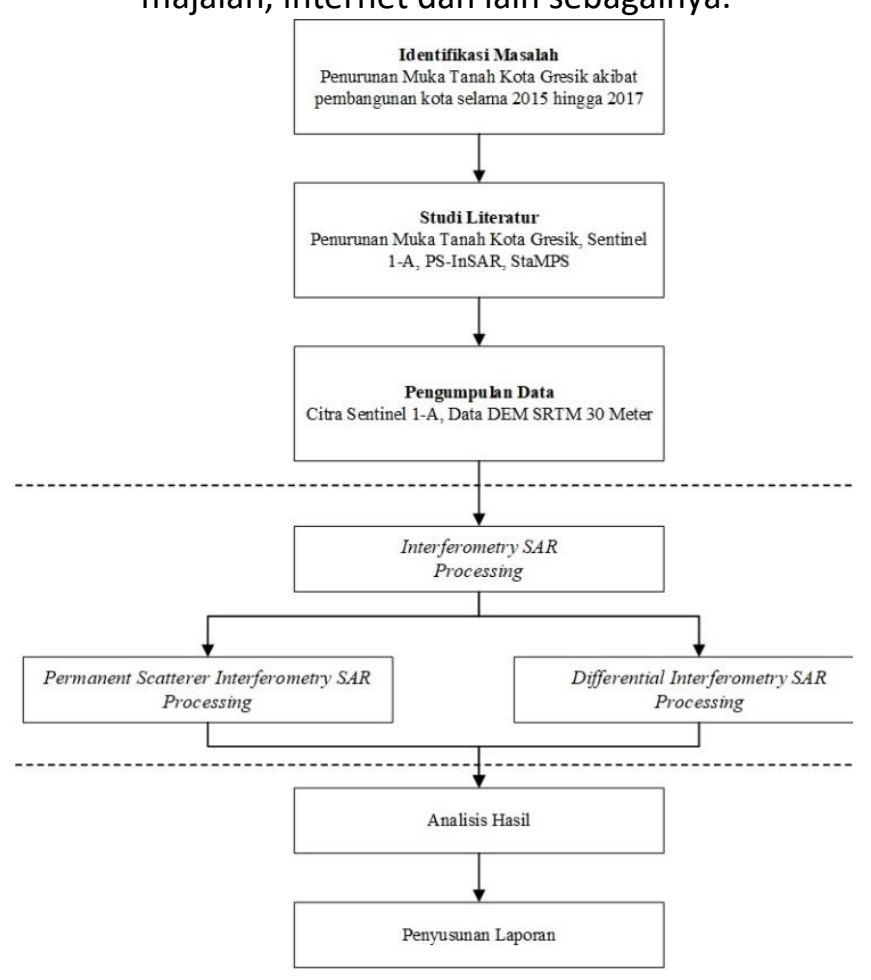

Gambar 2. Diagram Alir Pelaksanaan Penelitian

\section{- Pengumpulan Data}

Pada tahapan ini dilakukan proses pengumpulan data-data penunjang yang digunakan dalam penelitian untuk memperlancar proses pengolahan data. Adapun data-data tersebut diantaranya citra satelit Sentinel-1A level 1.0 (Single Look Complex), data DEM, data orbit dan data penunjang lainnya.

2. Tahap Pengolahan

Tahap pengolahan data pada tahap ini, data Sentinel-1A yang digunakan telah dalam format Single Look Complex (SLC) yang kemudian dilakukan pembentukan interferogram dari 23 citra Sentinel-1A dengan 1 citra sebagai citra master.

3. Tahap Analisa

Tahap analisis data dilakukan dengan membandingkan besar penurunan muka tanah kota Gresik dengan PS-InSAR dengan teknik StaMPS terhadap kondisi geologi daerah Kabupaten Gresik.

4. Tahap Akhir

Tahap akhir dari penelitian ini adalah pembuatan Peta Sebaran Titik Permanent Scatterer dengan metode PS-InSAR (Permanent Scatterer Interferometry Synthetic Aperture Radar) untuk analisis penurunan muka tanah kota Gresik Jawa Timur.

\section{HASIL DAN PEMBAHASAN}

\section{Citra Fase Interferogram}

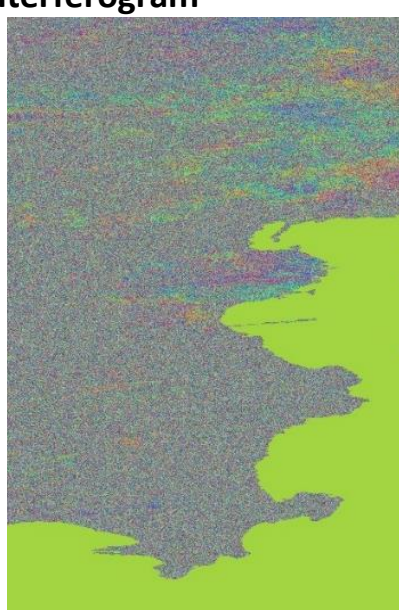

Gambar 3. Fase interferogram citra akuisisi April 2016 Mei 2015

Pengolahan set 13 data citra radar Sentinel 1-A di wilayah Kabupaten Gresik menggunakan metode PS-InSAR untuk mencari area tampalan (offset) dan komputasi.

Pada Gambar 3, hasil pembentukan citra interferogram berupa citra fase interferogram pada sistem koordinat radar dengan menggunakan DEM SRTM 30 meter untuk menghilangkan efek topografi.

\section{Koherensi}

Pada penelitian ini digunakan citra dengan koherensi antara citra master dan citra slave 
sebesar 0,2 hingga 0,3. Rendahnya nilai koherensi pada citra interferogram diakibatkan oleh wilayah penelitian didominasi vegetasi dengan kerapatan tinggi. Selain itu, pada daerah penelitian terdapat kawasan tambak yang merupakan kelemahan dari sistem radar. Kelemahan ini berupa hamburan balik gelombang (Backscatter) yang lemah.

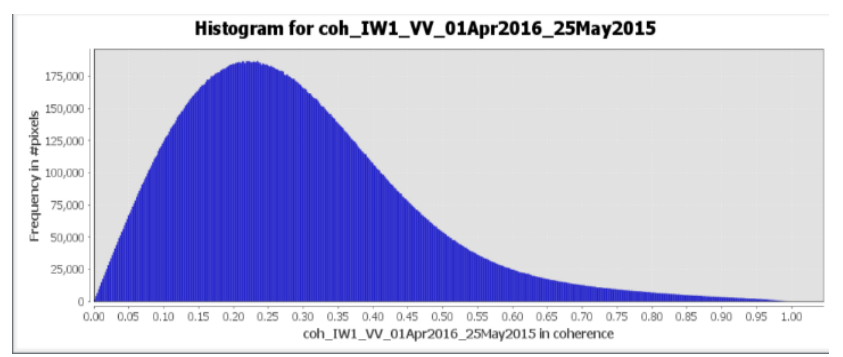

Gambar 4. Koherensi citra April 2016 Mei 2015

Selain dari faktor-faktor tersebut, dikarenakan interval waktu 12 hari pada pengambilan citra Sentinel-1A dianggap lebih lama dibandingkan citra ERS-1 yang memiliki interval waktu hanya 3 hari.

\section{Panjang Baseline}

Metode PS-InSAR pada pada dasarnya adalah merupakan metode InSAR dengan data multitemporal. Dari hasil pengolahan rentang waktu Mei 2015 hingga Januari 2017 didapatkan panjang baseline perpendicular yang tidak melebihi $150 \mathrm{~m}$.

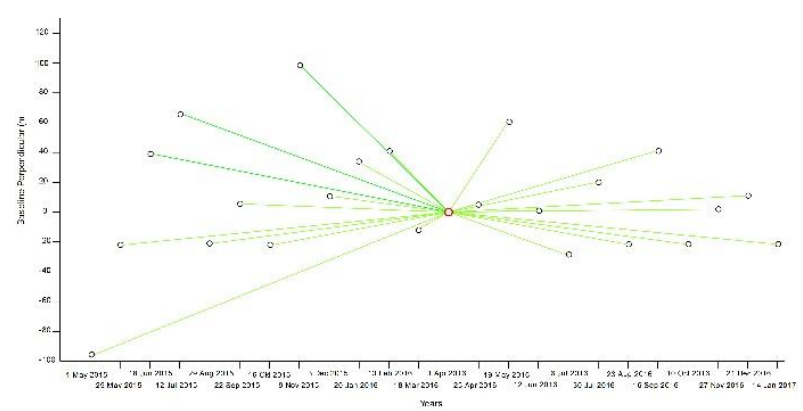

Gambar 5. Baseline Perpendicular

\section{Peta Sebaran Titik Permanent Scatterer}

Dari hasil pengolahan PS-InSAR menggunakan algoritma StaMPS tahap pertama diketahui bahwa pasangan citra tahap pertama mengalami penurunan permukaan tanah (deflasi) dengan nilai kecepatan penurunan paling tinggi bernilai $-61,3$ $\mathrm{mm} /$ tahun.

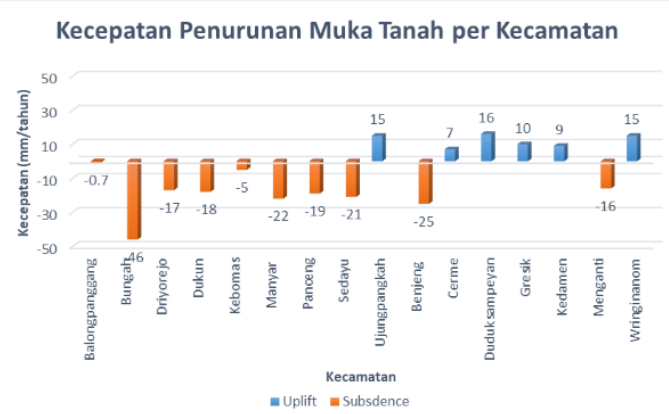

Gambar 6. Grafik Kecepatan Penurunan Muka Tanah

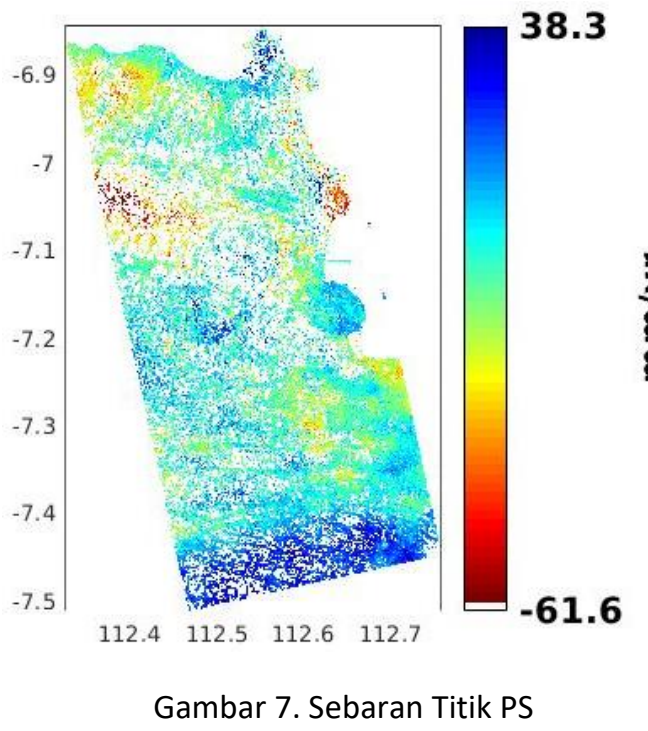

\section{Standar Deviasi}

Standar Deviasi adalah ukuran yang digunakan untuk mengukur jumlah variasi atau sebaran sejumlah set nilai data. Dalam pengolahan PSInSAR ini, data simpangan baku yang dihasilkan pada gambar di bawah ini :

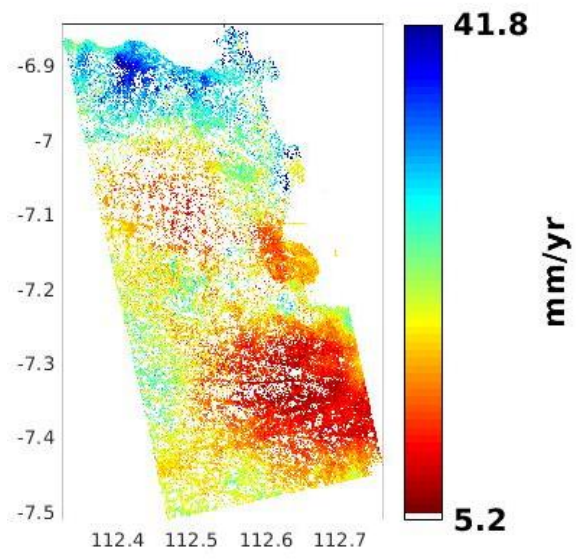

Gambar 8. Standar Deviasi Kecepatan Penurunan Muka Tanah 


\section{Analisa Terhadap Kondisi Lapangan}

Kondisi Geologi Kabpuaten Gresik didominasi oleh jenis tanah Aluvial. Pada dasarnya tipe tanah aluvial memiliki kerentanan terhadap daya topang beban (resistensi bobot) diatasnya. Penurunan muka tanah dapat secara visual diamati terhadap kondisi vertikal kedudukan bangunan-bangunan disekitar lokasi, retakan atau penurunan jalan aspal.

Selain dari faktor non-alam, proses tektonik yang terus berjalan mulai dari zaman Tersier hingga sekarang, banyak dijumpai adanya teras-teras sungai yang menunjukkan adanya perubahan base of sedimentation berupa pengangkatan pada Mandala Kendeng terutama pada wilayah Kabupaten Gresik juga menjadi salah satu indikasi dari penyebab penurunan muka tanah. Selain itu, 2 sesar yang aktif (Koulali dkk. 2016) diantaranya sesar Surabaya yang membentang mulai dari kawasan Keputih, Surabaya hingga Cerme, Gresik dan sesar Waru yang membentang mulai dari Rungkut, Surabaya hingga Jombang. Sesar Surabaya dan Sesar Waru tergolong dalam sesar naik sehingga pada polanya satu blok mengalami suatu kenaikan dan satu blok lainnya mengalami penurunan. Penurunan muka tanah akibat sesar turun tersebut terjadi pada Kecamatan Gresik di bagian Utara.

\section{KESIMPULAN}

Berdasarkan pengolahan dan analisis data yang telah dilakukan, berikut adalah kesimpulan yang penulis dapatkan dalam penelitian ini:

1. Dari hasil pengolahan dengan menggunakan metode PS-InSAR didapatkan estimasi besar deformasi berdasarkan Line of Sight (LOS) dengan nilai 5 hingga $-5 \mathrm{~cm}$.

2. Koherensi citra sebesar 0,2 tergolong rendah. Sebaiknya koherensi citra minimal memiliki nilai 0,3 dan rentang nilai ideal antara 0,5-1.

3. Metode pengolahan Citra untuk analisis penurunan muka secara multi temporal baiknya menggunakan teknologi terbaru pengembangan dari PS-InSAR yaitu SqueeSAR dengan perbaikan algoritma perhitungan sekitar $37 \%$.
4. Pengolahan PS-InSAR menggunakan perangkat lunak open source SNAP sangat potensial. Namun, diharapkan adanya perbaikan algoritme dalam operasi topo phase removal karena kurangnya variasi DEM selain yang diunduh otomatis oleh perangkat lunak.

5. Studi untuk analisis penurunan muka tanah sebaiknya menggunakan beberapa metode kombinasi agar menghasilkan variansi nilai sehingga dapat diketahui selisih dan rata-rata yang dihasilkan oleh tiap-tiap metode.

\section{UCAPAN TERIMAKASIH}

Penulis R.F.U mengucapkan terima kasih kepada Bapak Dr. Ir. Muhammad Taufik dan Ibu Ira Mutiara Anjasmara ST, M.Phil, Ph.D selaku dosen pembimbing yang telah memberikan dukungan dan bimbingan selama penelitian dilaksanakan.

\section{DAFTAR PUSTAKA}

Abidin, Z. 2013. Analisis dan Simulasi Parameter Radar Terhadap Performansi Synthetic Aperture Radar Pada Tahap Awal Pencitraan Sensor Radar. Malang: Jurusan Teknik Elektro Fakultas Teknik Universitas Brawijaya.

lodice, A. 2009. A Survey of Differential SAR Interferometry for Surface Displacement Monitoring. Proceedings of the 6th European Radar Conference, 212-214. Rome, Italy.

Ferretti, A., Monti-Guarnieri, A., Prati, C., dan Rocca, F. 2007. Submillimeter Accuracy of InSAR Time Series: Experimental Validation. leee Transactions on Geoscience and Remote Sensing, Vol. 45, No. 5, May 2007.

Hanssen, R. 2001. Radar Interferometry: Data Interpretation and Error Analysis Vol. 2. Springer.

Ketelaar, G., Van Leijen, F., Marinkovic, P., dan Hanssen, R. 2005. Initial point selection and validation in PSInSAR using integrated amplitude calibration, International Geoscience and Remote Sensing Symposium (IGARSS), 8, 5490-5493.

Koulali, A., Susilo, S., Mcclusky, S., Meilano, I., Cummins, P., Tregoning, P., Lister, G., Efendi, J., dan Syafi, M. A. 2016. "Crustal strain partitioning and the associated earthquake hazard in the eastern."

L. Tamm, T., Zalite, K., Voormansik, K., \& Talgre 2016. "Relating Sentinel-1 Interferometric Coherence to Mowing Events on Grasslands,"

Ferretti, A., Monti-Guarnieri, A., Prati, C., dan Rocca , F. 2007. Part B InSAR Processing : a Practical Approach. The Netherlands: ESA Publications. 
Mirzaee, S., Motagh, M., Akbari B., Wetzel H., Roessner S. 2017. "Evaluating Three Insar Time-Series Methods To Assess Creep Motion, Case Study: Masouleh Landslide In North Iran. ISPRS Hannover Workshop: HRIGI 17 - CMRT 17 - ISA 17 EuroCOW 17, 6-9 June 2017, Hannover, Germany. 